
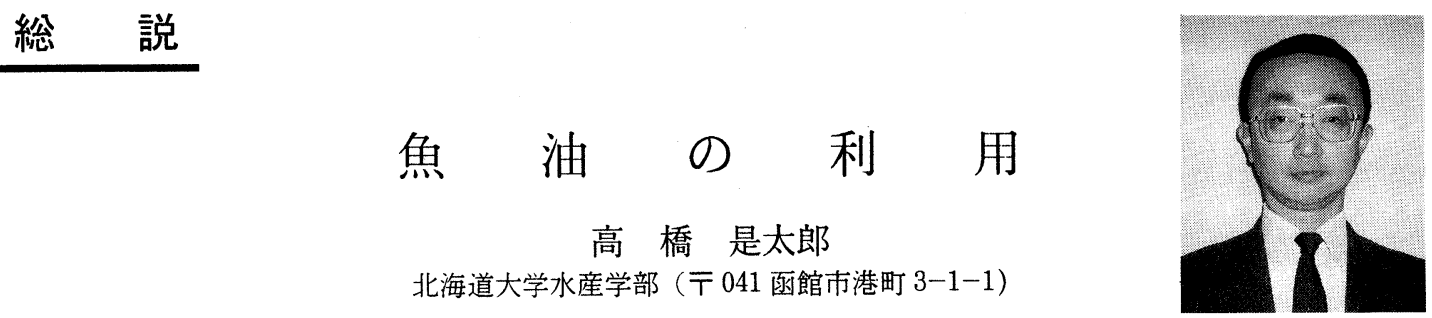

\title{
Modern Application of Fish Oil
}

Koretaro TAKAHASHI

Faculty of Fisheries, Hokkaido University

(3-1-1 Minato-cho, Hakodate-shi, T041)

Favorable characteristics and confronting problems in developing the modern application of fish oil are reviewed.

In order to expand the utilization of fish oil, daily and highly consumed linoleic acid and saturated fatty acids must be replaced in part by icosapentaenoic acid (EPA) and docosahexaenoic acid (DHA) concentrated fish oil, keeping the total lipid consumption at the level of modern Japan.

For this purpose, technology in modifying lipids including enzymatic synthesis of EPA and DHA rich simple lipids as well as phospholipids is considered to be impelled.

\section{1 はじめに}

“Modern Application of Marine Oils” と題したセ ミナーが 4 日間にわたってカナダのオンタリオ州で開催 される。主催は AOCS (アメリカ油化学協会) で, 来 年の 5 月 6 日から 9 日までの予定だそうである。これは 欧米が食品への魚油の本格的利用をめざす意気込みを示 す一例であろう。アメリカでは一昨年 (1989 年 9 月 15 日）に魚油の水添油ならびに部分水添油が FDA（連邦 食品・医薬品局)の GRAS (Generally Recognized as Safe ; すなわち一般に安全と認められる物質) 認定を 受(た ${ }^{1), 2)}$ 。また昨年 (1990 年 10 月 29 日) もあらゆる 形態の魚油が GRAS 認定を受け3)，い上い上魚油の食 品への利用が本格化しつつある。折しもこれと前後して イギリスやデンマークをはじめとするヨーロッパ 5 か国 とアメリカ, チリの共同で未水添魚油を添加したマーガ リンの試作と貯蔵試験, 官能評価が行われた くはサラダ油や肉製品への添加試験も行われることにな るであろう。今まで魚油の生産と利用に関してはわが国 に一日の長があったが, このように欧米における水産油 脂に関する研究の活発化は, 消費者の魚に対する健康イ メージに牽引されて今後ますます加速される様相を呈し てきている。

最近，わが国では SCRC-2738 (Alteromonus の 1 種) ${ }^{5) \cdot 6)}$ や 20-17 (Mortierellu alpina) $)^{7), 8)}$ を用いて
$\mathrm{EPA}$ を生産する技術が開発され，とくに国内で多くの 注目を集めている。これらの微生物が産生する高度不飽 和脂肪酸 (HUFA) は, 組成が魚油に比べ単純であるこ とから不要な脂肪酸を除くことが魚油よりも容易であ り, しかも SCRC-2738 株では HUFA を生理活性の 非常に高いリン脂質の形態で得られる等利点が多い。ま た，後述のような魚臭や着色の心配が少ないこと，セ卜 レン酸やエルカ酸（心疾患の原因）を含まないといった 点にも優れ, 実用化への幾つかの問題点さえ解決すれば, とくに医薬品への利用に関しては今後極めて有望といえ る。しかし, 機能性食品（薬務行政との整合性を図る意 味から平成 2 年 11 月以降は特定保健食品と呼ぶことに なっている）への利用に関しては魚に対する健康イメー ジ，DHA を産生する微生物が見あたらないこと，また 価格の点からいっても当分の間は魚油の優位は崩れそう にない。とくに欧米ではやや短絡的ともいえるほよ゙“魚 =健康” のイメージが強く ${ }^{9)}$, 微生物源 HUFA は食品 へ利用されにくい状況にあるといえよう。

\section{2 わが国における魚油の利用の現状}

昭和 63 年の農林水産省の統計によると水産油脂の全 国内生産は 48.6 万七であり，これは全世界の $32.7 \%$ に 当たる。

わが国の魚油の輸出は 34.7 万 $\mathrm{t}$, 国内分は 13.9 万 $\mathrm{t}$ で あり，そのうち消費されたものは 10.8 万しとみなされ， 
内訳は圧倒的に硬化油が多い。この理由は後述のように 硬化油にしてまず安定性を賦与しなけ枕ば劣化が速やか に起こってしまい, 商品価値を失ってしまうからに他な らない。硬化油はそのほとんどが業務用マーガリンや ショートニングに向けられている。業務用マーガリンの 多くは製菓, 製パンのほか調理, 加工食品等に利用され るもので，それぞれの用途に応じた加工特性を要求され る。現在マーガリン用に使用される硬化魚油は融点 35 ${ }^{\circ} \mathrm{C}$ 前後の選択水添油が多い。欧米のように未水添の魚油 をそのまま混合してマーガリンを造ろうとする試みはわ が国では今のところ 1 例だけ $\left(\mathrm{DHA}\right.$ の混合例 $\left.{ }^{10)}\right)$ のよ うである。

ショートニングとは水を含ま如可塑製油脂のことをい い, JAS (日本農林規格) では油脂を急冷的り合わせを して造られた固状のもの，または乳化剂などを加えて造 られた流動状または固状で可塑性, 乳化性等の加工性を 賦与したものと定義している。最近, 各用法に適する製 菓特性を強調したショートニングも開発されている。硬 化魚油を使用したショートニングは抱気, 練り込み, 展 延性を具備させた多目的型が多いので, ベース油にはこ れらの加工性を発揮できる改質が水添に望まれることに なる。幸い, 硬化魚油は脂肪酸, アシルグリセリン組成 に広い分布を示すものが多いので，熱処理などによる結 晶形の安定化などに影響をうけにくい長所が可塑性油脂 加工に活かされている。また, 選択水添による硬化魚油 からは他の固形脂に比べると口融けのよいものが得やす いといわれている11。

その他の魚油の詳しい利用例は成書に譲るが, 魚油の 特性をうまく活かしたものとしてはペイントが挙げられ よう。魚油は酸化重合しやすく, この点が通常は非常に 厄介な問題とされているが, 他方で重合油の“垂れ下が り”防止効果や耐水・耐久性に優れる点が利用され, ペ イントの原料として重宝されている。

以上の上うに硬化魚油や重合油は魚油にしかみられ ない優れた特性を有しているが，反面いまだに EPA， DHAに由来する優れた生理活性を活用し得ていない状 況にあるといえよう。これを活かしている例としては,

養魚用油としてわずかに $6000 \mathrm{t}$ 程度が消費されている 例があるに過ぎい。既に EPA，DHAによって多く の種類のし(仔)稚魚が順調に生育することは知られてお り ${ }^{12) \cdot 13)}$ ，エネルギー源としての油脂添加によりじ(餌) 料中のタンパク質含量を節減することは高価なタンパク を節約できるだけでなく ${ }^{14)}$ ，環境水中への窒素負荷の削 減にも有効であり, 養魚場の自家污染改善の点からも今 後一層検討されるべきであろう ${ }^{15)}$ 。

$\mathrm{EPA}$ 製剂としての消費も 10 年ほど前よりあるが国 内においては顕著な消費拡大はなく, 消費量そのものも 少ない。

\section{3 魚油の利用と品質管理に関わる諸問題}

\section{$3 \cdot 1$ 魚 臭}

魚油が酸化油臭を発生しやすい理由の第一に, 一般に HUFA が多いことが挙げられる。しかしそれだけでは なく，魚油はもともと天然の酸化防止性物質含量が他の 油脂よりも少ないことや酸化防止剤そのものが効果を発 揮しづらいこと ${ }^{16)}$ もきく影響している。また，着色 を加速するといわれるタンパク質分解物と結合しやすい こと, へム化合物に富むことも一層酸化に拍車をかける ことになる ${ }^{17)}$ 。とくに第三級窒素塩基のトリメチルア ミンやコリンが深く関与していることが古くから知ら れている ${ }^{18)}$ (一方ではあるレベル以上アミン類 ${ }^{19)} や コ$ リン ${ }^{20)}$ を添加するとむしろ脂質酸化を抑制するという 報告もある)。これら含窒素化合物はまず HUFA 亡結 合し, 次いでこのものが酸化, 魚臭を発生したり, 着色 したりすると推察され，このとき窒素量が多く不飽和度 が高いほよ゙魚臭も強くなるといわれる。したがって魚油 の品質保持のためにはあらかじめできるだけこのような 窒素化合物を除去しておくことが必要である。今までの ところ魚油の脱ガム, 脱色工程を経て通常窒素 $10 \mathrm{mg} /$ 油 $100 \mathrm{~g}$ 程度にまでは魚油中の窒素量を減らせる。

アメリカやカナダでは酸化魚油から発生する不快臭を “fishy”という単語一語で言い表しているが，魚油具は 魚種によって大きく異なっている ${ }^{21)}$ 。例えばメンへー

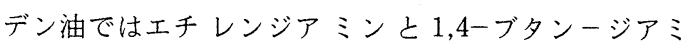
ン ${ }^{22)}$, いわし油では cis-3-ヘキセン-1-オール ${ }^{23)}$ の存 在が特徴であり, これらがそれぞれ“メンヘーデン油臭 さ”, “いわし油臭さ”に強く関与しているものと推察 されている。

ところで現在生産されている魚原油の大半は原料の集 荷に便利な地域の魚かす(粕)製造工場で分離されたもの である。魚原油は原料に直接または間接的に熱を加えて タンパク質を熱変性させることにより水分や油脂分の分 離を促進して得られるので, 熱によるメイラード反応の 進行によりピラジン系化合物やアミン類が生じ, この臭 気が油脂分に移行することによって魚原油特有の魚臭さ を呈するようになる。この傾向は原料の鮮度が低下する ほよ゙著しくなるが, 多くの場合脱酸, 脱色を主とする精 製工場に集められて脱臭工程を経ればほとんど無臭とな る。しかしながら直ちにかなりの低温下に精製魚油を保 存しない限り, 短時間のうちに魚油特有の不快臭を発す るようになる。このときの臭気の本体は HUFA 由来ア ルケナールの 2,4,7-デカトリエナール24) 26) や 4-ヘプ テナール27) 28) 之, アルカナールのヘプタナールやプロ パナールである。これらはいずれもしきい(闇) 值が低 く ${ }^{29)}$ かつ分解されやすい到, ${ }^{20)}$ といわれる。一般に, 水 添によって酸化に対する安定性は増し, 酸敗にともなう 
不快臭の発生を著しく抑制することができるが，それで も水添 HUFA からしきい値の非常に低い6-ノネナー ルが発生することがあり ${ }^{31)}$,これによって酸化臭を呈す ることがさけられない場合もある。

現在脱臭工程は酸素を含まない水蒸気によるものが大 半であるが, 水蒸気と揮発性酸の併用 ${ }^{32)}$ や, あらかじ め魚油にグリセリンをモノアシルグリセリン (MG) を 介して添加しておいてから高真空で脱臭する ${ }^{33) \cdot 34)}$ と いった試みもなされている。なお, 脱臭プラントに関し ては成書 ${ }^{35)}$ を参照されたい。

Ikeda と Fukuzumi ${ }^{36)}$ によれば $36.5^{\circ} \mathrm{C}$ 下での酸化 の速さ（誘導期を終えるまでの早さ）はメチルエステル (ME) 間の比較ではオレイン酸メチル：1に対してリ ノール酸メチル : 8, リノレン酸メチル : $21.7, \mathrm{EPA}+$ DHA メチル : 31.9 になるといわ机, また, $\mathrm{Cho}^{37)} ら$ によればエチルエステル $(\mathrm{EE})$ 間の比較では誘導期間の 長さで比較した場合, $5^{\circ} \mathrm{C}$ 自然酸化条件下でリノール酸 エチル : $50 \mathrm{~d}$,リノレン酸エチル : $20 \mathrm{~d}, \mathrm{EPA}+\mathrm{DHA}$ エチル：3〜4 d になるといわれる。同氏らはこの系に おいて, 誘導期間終了後の吸収酸素量が EPA エチルで リノール酸エチルの 5.2 倍, DHA エチルで 8.5 倍にも なることをみている。さらに同氏らは， $5{ }^{\circ} \mathrm{C}$ ないて 90 $\operatorname{lux}$ の光を当てると EPA エチルと DHA エチルは酸化 の誘導期すら認められなくなり, 同条件下 $2 \mathrm{~d}$ における 酸素吸収量はリノール酸エチル：1に対してリノレン酸 エチル : 99, EPA エチル : 743, DHA エチルでは 948 にもなることを明らかにしている。

以上のようにEPA や DHA を含む魚油が酸化に対し て極めて弱いことはよく知られており, この理由として は EPA や DHA がその分子内に 1,4-ペンタジエン系 を有することに加え，メチレン基が両側の二重結合に挟 まれている構造をもつために酸化の活性化エネルギーが 著しく低下することが挙げられている。しかし，植物油 の精製魚油への混合により誘導期が著しく延長されるよ いうデータもあり, 解釈が単純にはいかない面も多い。

\section{$3 \cdot 2$ 酸化度の判定}

リノール酸を主体とする植物油の酸化度判定には過酸 化物価 (PV) が最も広く用いられている。これは初期 酸化においてリノール酸では吸収された酸素のほとんど がまず過酸化物 の形で一たん蓄積するので, 酸素吸収 量そのものを定量する上での誤差が比較的少ないことが 挙げられる。ところが魚油では過酸化物は速やかにアル デヒドを主とする二次産物に変化するため, 吸収された 全酸素量に占める過酸化物中の酸素量は 50 ～70\% に過 ぎず21).38).39), PV を過信することには問題があると考 える研究者が多くなってきている。

精製魚油を自然酸化させると, PV が低くてもにおい が発生する, このにおいを脂質二分子膜センサーで検出
し定量化する試みがあるが ${ }^{40)}$, 数値化はできても再現性 や定量性に解決すべき問題が多い。しかし, 現実にはも よ゙り臭の発生が魚油の品質を極めて大きく左右するので 今後検討していってもよい方法と考える。

いずれにしても, 現時点では魚油の酸化度を一指標だ けで適切に示し得るまでには至っていない。

\section{$3 \cdot 3$ 高度不飽和脂肪酸の定量}

HUFA の定量にはガスクロマトグラフ (GC) が広 く用いられている。これはいうまでもなく GC により 極めて簡単に, しかもごく少量 (ng の単位) の試料で も HUFA の定量が可能だからである。しかしながら GCの宿命ともいうべき熱により HUFA が一部変質し, 定量性を損なう場合も少なくない。そこで, トリコサン 酸 $\left(\mathrm{C}_{23: 0}\right)$ 等 ${ }^{41)}$ を内部標準物質として回収係数を乗じて 定量することが考案されている ${ }^{42)}{ }^{43)}$ 。すなわち,

$$
\mathrm{EPAmg} / \mathrm{g}=\frac{A_{\mathrm{E}} \times \text { 内部標準物質の重量 } \times 0.99^{*}}{A_{\mathrm{IS}} \times \text { 試料の重量 } \times 1.04^{* *}}
$$

ただし， $A_{\text {IS }}$ は内部標準物質のクロマトグラム上の面 積, $A_{\mathrm{E}}$ は EPA の面積, “*”は検出器の応答係数 (DHA は 0.97), “**”は $\mathrm{ME}$ 化したことによる補正係数を表 す。セラコレン酸 $\left(\mathrm{C}_{24: 1, n-9}\right)$ はトリコサン酸に比べて 溶解度が高く, 扱いやすいがポリグリコール系カラムで はDHA と極めて近くに溶出するため不都 合が生じ る場合がある ${ }^{44}$ 。HUFA を GC で分析するためには HUFA $\mathrm{ME}$ に誘導してカルボキシル基のクロマト系 への影響をなくすとともに安定性を賦与させることが必 要であるが, この $\mathrm{ME}$ 化には加熱がともなうため幾分 の EPA，DHA の損失を生じる場合がある。例えば 封管によるメ夕ノール性塩酸の $\mathrm{ME}$ 化反応は明らかに PrevotとMordret ${ }^{45)}$ のアルカリ低温 ME 化法よりも 低い EPA, DHA の定量值を与える。Tande と Gran$\mathrm{vik}^{46)}$ は 4 通りの ME 化法について比較検討し, 三塩化 ホウ素とテトラメチルグアニジンによる方法が HUFA の損失が最も少なく, 三フッ化ホウ素よりも優れている としている。なお, 最も簡単な方法としては脂質のエー テル溶液に市販（イーストマンコダック社）の水酸化テ トラメチルアンモニウムメタノール溶液を加えるだけと いった例 ${ }^{47)}$ がある。この方法は加熱を必要としない(室 温）ので最も穏和な ME 化条件といえる。

脂肪酸組成の分析を行うのにポリエチレングリコール 系やカーボワックス系の強極性キャピラリーカラムを用 いることは今や常識となりつつある。キャピラリーカラ ムの歴史は意外なほど古く, 30 年ほよ゙以前にまでさか のぼる。最近はカラムそのものの取り扱いが楽になった ことやスプリットレス分析も簡単にできるようになって きたことから急速に普及してきてはいるが，いまだに

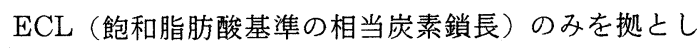
て GC クロマトグラム上の脂肪酸を同定できるまでに 
は至っていない。これはカラムロット間のばらつきによ るものと考元ら机ており, この点の改善が今後の課題で あろう。しかしながら一昨年ころよりロットのばらつき の少ないカラムが出始めてきており ${ }^{48)}$, 今後はECLに よる簡便な同定も可能となってくるに違いない。

\section{$3 \cdot 4$ 分子種の分析と定量}

昨今魚油の改質に関する研究が盛んに行われている が，原料となるべき魚油の分子種組成についてはその分 析が困難なことからほとんど知見がなく，このためこの 種の研究は試行錯誤的に行わ机ているのが実状である。 魚油のトリアシルグリセリン (TG) の分子種は主な脂 肪酸を 6 種と限定し, 立体異性体を考慮しなくても $\left(6^{3}\right.$ $\left.+3 \times 6^{2}+2 \times 6\right) \div 6=56$ 種の存在が可能となる ${ }^{49)}$ 。さら に脂肪酸を 10 種とすれば 132 種と著しく分子種の種類 が増える。魚油 TG の個々の分子種の存在とその量的 関係を明らかにするためには少なくとも数十万段以上の 理論段数 (カラム効率) は必要であり, 現状の高速液体 クロマトグラフ (HPLC) では不充分といわざるを得な い。現在のところ組成が比較的学純なアシル基が 2 個の リン脂質については GC とHPLCによって魚種ごとの 分子種がある程度明らかになっている

クロマトグラフィーにおける脂質分子種の分配を支配 する因子は, 固定相及び移動相分子亡脂質分子間に生ず る van der Waals 力の総和によると考えられる ${ }^{62)}$ 。逆 相 HPLC ではvan der Waals 力のうちとくに有極性の エチレンユニット(二重結合部)の数とそ扎らの相対的距 離に基づく双極子モーメントならびに van der Waals 半径の影響が大きいと考えることができ，脂質分子の立 体的な分子構造よりこの両者の相対保持値に対する寄与 率さえ明らかにできれば，将来は GC と同梯の簡便さ で分子種の同定が可能となることも予想される。しかし それには HPLC の分解能, 再現性, 精度を飛躍的に高 め权ばならず, 目下ハード面での性能向上が最大の課題 といえよう。

\section{5 化学的処理による着色と脂肪酸の異性化}

高濃度の HUFA を得るには魚油の加水分解は避けて 通れない工程である。この加水分解の工程には高圧・高 温処理, 酸処理やアルカリ処理が用いられるが, いずれ の方法も着色や重合, 異性化等の副反応が起こりやすい。 また，油脂の改質にしばしば用いられる触媒や脱水縮合 剤にも同様の弊害がみられる。一たん魚油が着色してし まうと脱色には相当手間取ることになる。しかもパーム 油のように脱酸工程を経ることなしに脱色をすることは 事実上できない。通常 $80^{\circ} \mathrm{C}$ 以下で活性白土を通せば着 色が残り, 反対に $120^{\circ} \mathrm{C}$ 以上では, “色戻り”が起こるこ とになる。また,この温度では活性白土自身が酸性触媒と して働き，異性化や環状化をも起こしてしまう63)。水 添の過程においても触媒による異性化は避けられず，亡
くにトランス酸の生成がデサチュラーゼへの阻害効果や 冠状動脈への悪影響の䯚念から問題とされている 64) 66)。重合して変質した脂質は後に続く工程で除去さ れるが，二重結合の転移が起こったものは除去が困難に なる。二重結合の転移は決定的に生理作用が変わってし まうので，この副反応の進行は最も注意を要する。

\section{6 好ましくない脂肪酸の存在}

魚油中に多量に含まれる EPA やDHA の有用性につ いては広く一般にも知机たるところとなった。しかし 魚油は一方で心疾患の原因になり得るといわれるセトレ ン酸やエルカ酸を含むことが指摘されている。これら炭 素数が 22 個の脂肪酸は多量に摄取するとそれが心臟や 肝臓に蓄積し, ミトコンドリア機能を変えたり,ペルオ キシソーム(細胞小器官の一種で各種の酸化酵素を含む) 誘導を引き起こしたりするともいわれ，この意味におい ては DHA も過剩に摂取すれば同様の危険が生じるこ

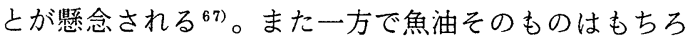
んのこと, 市販の EPA カプセルでさえ HUFA と同量 の飽和脂肪酸が入っている場合もみられ ${ }^{68)}$ ，この場合に は LDL を減らす効果は期待できないことになってしま う。

以上の点から,やはり魚油といえども適量摄取が原則 となることは他の栄養素と全く同様である。さらに付け 加えるならば, HUFA の摂取に当たっては摄取後の生 体内酸化により体内に有害な活性酸素の発生を防ぐため にトコフェロールや地域によってはグルタチオンペルオ キシダーゼ（体内過酸化水素の除去酵素）を賦活化する セレンを併せて摂る等の工夫が必要であることを忘れて はならない。

\section{4 高度不飽和脂肪酸の調製}

\section{$4 \cdot 1$ 化学的 -物理的方法}

いわし油を液体窒素で $-40^{\circ} \mathrm{C} \sim-80^{\circ} \mathrm{C}$ に急冷し，速や かに沪過すると沪液に HUFA が濃縮される。この方法 は脱ろう, あるいは低温溶媒分別法と呼ばれ，最大 40 $\%$ 程度までの HUFA の濃縮が可能であり ${ }^{69}$, 変質もほ とんど起こらない。しかしかつお油のようにこの方法を 適用できない場合もあり，またエネルギーの消費量も決 して少ないとはいえない。HUFA の濃縮限界が 40\%前 後によよ゙まる最大の理由はその分子種組成にある。まだ 充分には明らかにされていないが，比較的脱ろうが容易 ないわし油でさえ EPA と DHA のみより成る TG 分 子種は少なく, 二酸型, 三酸型の分子種が圧倒的に多い といわれる。したがって HUFA そのものの融点は低く ても, 同一分子内の他の脂肪酸の融点が高ければ全体之 しての融点は平均化されてしまうことになり，融点差に よる分離は不充分となる。かつお油ではこのことに加え， TG 分子内に HUFA を一個しかもたない分子種がさら 
に多く存在し，しかも HUFA を全く含まない TG 分子 種がいわし油よりも少ない。このことは脱ろうそのもの をも困難にする原因となる ${ }^{70)}$ 。

以上の理由により魚油に化学的処理もしくは酵素処理 をすることなしにHUFA を高濃度にすることは今の時 点では不可能である。そこで通常はまず魚油を加水分解 して遊離脂肪酸（FFA）を得るか，アルコリシスに よって EE を得, これらを低温溶媒分別法 ${ }^{71)}$ や尿素付 加法 ${ }^{72)}$,塩形成法 ${ }^{73)}$,超臨界二酸化炭素抽出法 ${ }^{74)}{ }^{79)}$ 等 に供して高濃度の HUFA を得ることが行われている。 これらの手法によって $70 \%$ 程度の濃縮は比較的容易に 達成される ${ }^{80)}$ 。筆者が訪ねたシアトルの National Marine Fisheries Service では尿素付加法と超臨界二酸化 炭素抽出法の組み合わせで $96 \%$ 純度の EPA を得るこ とに成功している ${ }^{81)}$ 。同研究所の試算によると $90 \%$ 純 度の EPA は $10 \mathrm{lb} / \mathrm{d}$ 程度の小プラントで原料費を除き $1 \mathrm{lb}$ 当たり 100 ドル程度という。超臨界二酸化炭素抽出 法よりも経費のかからない尿素付加法でも $0.01 \%$ の没 食子酸オクチルの併用によって魚原油 $1 \mathrm{~kg}$ から $265 \mathrm{~g}$ (85\% 濃度) の HUFA の調製に成功した例がある ${ }^{82)}$ 。 その他, 動物投与実験のためのみの用途としては EPA を $\delta$ ラクトン化合物, DHA を $\gamma$-ラクトン化合物に改 変し, EPA と DHA の安定性の差を利用して両者を分 けて得る方法もあり ${ }^{83)}$ ，84) また経費はかかるが確実な方 法として分取 HPLC を用いる方法 ${ }^{85)}$. 86) が既に 4 年程 前より工業化されている。

ごく最近, DHA と銀イオンの間に強い引力が働くこ とを応用して低廉に DHA を取り出す技術が発表され た ${ }^{87) ~ 89)}$ 。銀化合物之不飽和脂肪酸が可逆的に極性複合 体を形成することを応用した順相クロマトグラフィーは 古くから知られていたので着想そのものはいわゆるコロ ンブスの卵であるが, 硝酸銀の安定的使用と漏出防止法 が工夫点となっている。

農林水産省の主導によって“食品産業におけるハイセ パレーションシステムの開発”の各関連プロジェクトが 機能し, 脂質関連の分野においても膜分離技術の応用に よる脂質関連生理活性物質の分離精製が成功しつつあ り，今後の進展が期待されている。

\section{$4 \cdot 2$ 酵素の利用}

大量にしかも連続的に脂肪酸やグリセリンを得る目的 で高圧分解法が現在広く用いられている。しかしHUFA のように不安定な脂肪酸を比較的小規模に生産しよう之 する場合には酵素の利用の方が向いている場合も少なく ない。しかも酵素の基質特異性（脂肪酸特異性や部分ア シルグリセリン特異性)や位置特異性をも活用できれば, 物理的性質の極めて接近した多くの脂肪酸の中から目的 の脂肪酸だけを分画することも可能となり，はかりしれ ない魚油の高度利用が将来期待できよう。
このような理由から最近種々のリパーゼを用いた魚油 の改質に関する研究が活発化してきた。リパーゼやホス ホリパーゼの利用法と理論に関しては本号の “脂質関連 酵素の利用”に詳しいのでここでは概略を紹介するによ どめることにする。

魚油の改質にリパーゼの基質特異性を利用した研究は 昭和 58 年の村瀬らの研究 ${ }^{90)}$ に端を発している。その後

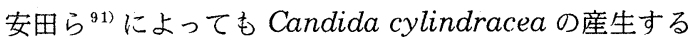
リパーゼは相対的に DHA をグリセリン残基に残すこ とが見いだされ，同氏らはエステル交換の併用によって 2 倍程度の HUFA 濃縮に成功している。星野と山根に よってもこのことが確認され，さらに同氏らはAsperg illus niger によっても HUFA が 2 倍以上濃縮される ことを明らかにしている ${ }^{92) 94)}$ 。 Aspergillus niger は ジアシルグリセリン (DG) をある程度蓄積するので完 全な1,3一位置特異性リパーゼとはいえないが魚油は $s n$

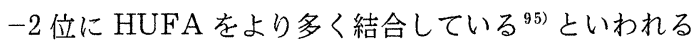
ので, 本酵素の場合は基質特異性のみならず位置特異性 も HUFA の濃縮に関与しているものと思われる。なお, アシル基転移による未水解アシルグリセリンの回収量低 下を防ぐためには，反応温度を $15 \sim 40^{\circ} \mathrm{C}$ 範囲に設定 することが必要であることが知られている。一般に上記 のような Candida cylindracea や Aspergillus niger に限らず DHA はリパーゼの加水分解作用を受けにく いといわれる。この理由は定かではないが, カルボキシル 基近くに二重結合をもつとリパーゼの作用を受けづらく なることが経験的に知られているほか, Bottino ら ${ }^{96)}$ は HUFA の分子形状に由来する末端メチル基のエステル 結合部に対する立体障害を挙げている。Brockerhoff ${ }^{97)}$ は脂肪酸残基の $\Delta 2 \sim \Delta 5$ の間に二重結合を導入すると 加水分解されづらくなることをみている。一方, DHA に限らず中野と木村 ${ }^{98)}$ ， 99) によって EPAをグリセリン 残基に残すリパーゼを産生する微生物も見いだされてい る。

このようにリパーゼの特異性を利用した HUFA の濃 縮が研究されている一方で, HUFA の濃縮を加水分解 後の工程に讓り, 加水分解そのものの効率を上げよう之 する試みも現在並行して行われている。村瀬ら ${ }^{100)}$ は位 置特異性を有するリパーゼと有しないリパーゼを併用し て加水分解率を向上できることを見いだし，さらに脂肪 族アルコール (一価) を添加することによって逆反応で ある合成反応を抑制し，一層の加水分解反応の促進が可

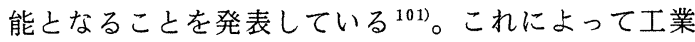
ベースにのるといわれる $90 \%$ 以上の加水分解率を得る ことが既に可能となった。一方藤吉ら ${ }^{102)}$ はこの 2 年後 にこれとほぼ同等かそれ以上 (95\%前後) の加水分解率 をAspergillus japonicus の単独使用で得ることに成 功している。 
さて，4.1で述べたように加水分解後の FFAもしく は脂肪酸エステルを濃縮する常とう(套)手段は物理的あ るいは化学的方法であった。しかし最近 Mucor miehei 由来の固定化酵素 (リポザイム) を FFA と脂肪酸 $\mathrm{ME}$ の混合液中で作用させることにより FFA 画分に DHA を濃縮する方法や，同酵素を触媒とするアシドリシスに よってもFFA 画分にDHA が残存し，濃縮が可能にな るという報告 ${ }^{103)} も$ 出ており, リパーゼの脂肪酸特異 性を活用した方法として関心がもたれている。さらに Hills ら ${ }^{104)} も$ 同固定化酵素によって混合脂肪酸のブチ ル化反応を行い，平衡になる前に反応を停止すれば未反 応物中に DHA が濃縮できることをみている。また同 氏らはなたね由来のリパーゼによっても同様の方法に よってDHA を濃縮できることを見いだしている ${ }^{105) 。 ~}$ これらはいずれもたら肝油を原料としているが, 他の水 産油脂にも適用できることは明らかである。

\section{5 組み立て脂質}

\section{$5 \cdot 1$ 高濃度高度不飽和脂肪酸含有単純脂質の合成}

先にも述べたように従来の“機能性食品” は“特定保 健用食品” と名称を变え, 栄養改善法第 12 条に規定す る特殊栄養食品の一つとして位置づけられることになっ た。これによってヘルスクレーム(食品の健康強調表示) の国際的整合性への路が開かれ, 今後いよい上本格化段 階に入るもの亡思われる。

EPA や DHA を摂取する形態には TG, DG, MG, $\mathrm{EE}, \mathrm{FFA}$, リン脂質の 6 種類が考えられる。このうち いずれの形態を選択すべきかは目的によって異なる。す なわち食品としての利用を主眼とする場合にはアシルグ リセリンやリン脂質が向いており，即効性を重視して糖 尿病用薬剤やリュウマチ性関節炎の治療に用いるには FFAが向いているともいえよう。

リパーゼを用いたアシルグリセリンの合成は Iwai ら ${ }^{106)}$ の研究に端を発し, HUFA 含有 TG の合成に関 しては山田と藤田 ${ }^{107)}$ の試みが最初であろう。船田と田 中 ${ }^{108) \sim 111)}$ は Candida cylindracea ¿ Chromobacterium viscosum のリパーゼの特性を活用し, へテロ 型バイオリアクターに上る魚油の改質の連続化に成功し ている。油一水の酵素反応の上うに不均一の反応系に適 したバイオリアクターの開発に当たっては(1)乳化剂を用 いずに酵素水溶液中に油脂を効率的に分散させて反応の 効率を高めること(2)酸素に対して極めて安定性の悪い魚 油を基質に使うため，空気を反応系中に巻き込むリアク ターは避けること(3)連続運転が可能なこと等の点が基本 概念となる。(1)に関しては分散板を多段化することに よって油脂之酵素液との接触面積の拡大と界面の更新を 図っており，(2)之(3)に関しては空げき(隙)が全くなくし かも油脂と酵素液との比重差のみによって油脂がリアク
ター内を移動する秪やかな様式とすることで油脂の酸化 を防ぐとともに連続化を可能にしている。加水分解反応 生成物からの部分アシルグリセリンの回収には遠心液々 クロマトグラフィーを用いている。これにより FFA を ほとんど含まない高濃度部分アシルグリセリンを連続的 に得ることができ, 次ぎのエステル交換工程に移って改 質 TG が製造されることになる。この他魚油にも適用 できるエステル交換法として高橋と蔵重 ${ }^{112)}$, 国生ら ${ }^{113}$ の特許, MG に所望の脂肪酸を導入する岡畑 ${ }^{114)}$ の特許 がある。

一方，エステル交換反応によらなくても単に HUFA を高濃度に含む混合 FFA から直接 Chromobacterium viscosum 由来の酵素で高濃度 HUFA-TG を合成 する方法もある。HUFA が $69 \%$ 程度の混合 FFA から 少なくとも $65 \%$ 以上の HUFA を含む TG を合成した 例がある。またそのとき合成された TG 中には HUFA を $\mathrm{TG}$ 分子内に 2 個以上含む分子種が半分以上を占め ていたといわれる115)，116)。

\section{$5 \cdot 2$ 高度不飽和脂肪酸含有複合脂質の合成}

リン脂質の中でもとくに HUFA を含有するリン脂 質の機能（本号の “リン脂質”を参照）については最 近次々と明らかにされ, これと連動するかのように厚生 省の主導による HUFA 含有リン脂質の生理機能の解 明, 水産庁主導による HUFA 含有リン脂質の給源調査 と抽出, 通産省主導による HUFA 含有リン脂質の製 造技術の開発といったプロジェクトが既に機能し始めて いる。HUFA 含有リン脂質の合成に関する研究は戸谷 $ら^{117), 118)}$, 稲田ら ${ }^{119), 120)}$, Yagi ら ${ }^{121}(\gamma$-リノレン酸 $)$ によるホスファチジルコリン (PC) やホスファチジルエ タノールアミン $(\mathrm{PE})$ と魚油 TGもしくは所望の FFA とのエステル交換反応の応用に始まる。エステル交換反 応による HUFA 含有リン脂質の合成に関しては無機触 媒による化学合成も試みら扎ているが, 著しい着色が 大きな問題とされている。また，グリセロホスホリルコ リン（またはグリセロホスホリルエタノールアミン）上 HUFA-FFA から酸無水物法, 酸クロリド法によって $\mathrm{PC}($ または $\mathrm{PE})$ を製造する方法もあるが, 脱水縮合剤, 塩酸等の触媒による HUFA の著しい劣化が問題視され ている。

以上の点から，良質のものを得るといった観点からは 明らかに酵素法が他の方法よりも優れているが, 現時点 では収量そのものが低いことが最大の欠点となってい る。

一方, リン脂質分子内での脂肪酸の占める結合位置も その活性発現に大きく影響することが昨今明らかにされ つつある。養魚餌料においては $s n-2$ 位に HUFA のつ いたリン脂質が望ましい場合があり ${ }^{122)}$ ，また松本ら ${ }^{123)}$ は一昨年 $s n-2$ 位に DHA を有する $\mathrm{PC}$ がアラキドン酸 
のロイコトリエンへの転換に対し強い抑制能を示したこ とを報告している。その中で同氏らはsn-1 位にオレイ ン酸, $s n-2$ 位に DHA を有する PC が両方に DHA を 有する PC よりもその抑制能が高いことも報告してい る。

リン脂質の $s n-2$ 位に HUFA を集中化させる研究は $\mathrm{Na} ら^{124)}$, Pernas $~{ }^{125)}$, 筆者 ${ }^{126)}{ }^{127)}$ によって相次 いで行われた。このうち衛生上問題がないと思われる反 応系はグリセリンを分散媒に選んだ系だと考える。しか もこの場合にはPCの合成率においても優れるといった 効果もみられる。Table-1にこのときの合成に用いた 基質の脂肪酸組成, 合成率, 合成された PC のsn-1 位, $s n-2$ 位それぞれの脂肪酸組成を示す。これら一連 の研究で成否を決めるかぎは水分量の調節と基質の効果 的分散である。現在, 反応率が低いことの理由の一つに 基質の分散が必ずしも充分でないことが挙げられよう。 一般にリパーゼは水溶性であるため有機溶媒との接触に より失活する場合が多く，また基質となる脂質もほとん
ごの場合親油性で水に不溶である。したがって反応系は 不均一な 2 層系となり, 必要以上の水が存在すると加水 分解方向へ平衡が傾き，エステル交換や合成が進行しな くなる。今後はこういった点の改善・最適化が課題とな ろう。

現在工業的にブタすい臟由来のホスホリパーゼ $\mathrm{A}_{2}$ を 用いて，大豆レシチンを原料として比較的低廉にリゾリ ン脂質を造れるようになった。またホスホリパーゼ $\mathrm{A}_{2}$ は DNA 組み換え法による酵母での生産 ${ }^{128)}$ も検討され ており，工業規模での HUFA 含有複合脂質の生産は決 して実現性の乏しいものではない段階に入ったといえよ う。

\section{6 今後へ向けて}

平均寿命からみるとわが国は現在世界一の長寿国之 なっている。ところが国民の有病率からみると明らかに 以前より悪化しており，この傾向は今後ますます助長さ れるものと予想される。厚生省ではこのような傾向に歯

Table-1 Fatty acid composition of substrates, synthesized PC and the $s n-1$ and $s n-2$ of it obtained by phospholipase $\mathrm{A}_{2}$ esterification ${ }^{126) \cdot 127)}$.

Prepared as substrates

\begin{tabular}{l|r|r|r|r|r|r}
\hline \multirow{2}{*}{ Substrate } & \multicolumn{6}{|c}{ Fatty acid (\%) } \\
\cline { 2 - 7 } & $16: 0$ & $18: 0$ & $18: 1$ & $18: 2$ & $20: 5$ & $22: 6$ \\
\hline LPC & 23.6 & 6.9 & 11.3 & 50.5 & 0.2 & 0.0 \\
Fatty acid mixture from fish oil----(A) & 15.2 & 4.0 & 15.2 & 2.0 & 14.0 & 8.9 \\
EPA, DHA concentrated fatty acid & 0.5 & 4.4 & 1.9 & 0.9 & 42.2 & 25.9 \\
mixture from fish oil--.(B) & & & & & & \\
\hline
\end{tabular}

Synthesized PC

\begin{tabular}{c|c|c|c|c|c|r|r}
\hline \multirow{2}{*}{ Substrate } & \multirow{2}{*}{ Yield (\%)* } & \multicolumn{6}{|c}{ Fatty acid (\%) } \\
\cline { 3 - 8 } & & $16: 0$ & $18: 0$ & $18: 1$ & $18: 2$ & $20: 5$ & $22: 6$ \\
\hline from substrate A & 13.8 & 19.8 & 4.8 & 13.3 & 29.3 & 6.0 & 4.0 \\
from substrate B & 14.8 & 12.6 & 5.2 & 7.4 & 28.0 & 20.1 & 11.2 \\
from 99.4\% EPA & 15.9 & 12.3 & 3.4 & 6.5 & 26.4 & 45.1 & 0.0 \\
\hline
\end{tabular}

Synthesized PC from substrate A

\begin{tabular}{c|r|r|r}
\hline \multirow{2}{*}{ Fatty acid } & \multicolumn{3}{|c}{ Synthesized PC } \\
\cline { 2 - 4 } & Total & \multicolumn{1}{|c}{$s n-1$} & \multicolumn{1}{c}{$s n-2$} \\
\hline $16: 0$ & 19.5 & 23.1 & 14.6 \\
$18: 0$ & 6.0 & 7.2 & 3.9 \\
$18: 1$ & 12.4 & 11.4 & 13.6 \\
$18: 2$ & 32.8 & 51.5 & 8.9 \\
$20: 5$ & 8.5 & 0.2 & 16.0 \\
$22: 6$ & 4.9 & 0.0 & 9.5 \\
\hline
\end{tabular}

${ }^{*} \mathrm{PC} \% /$ Phospholipid. 
止めをかけるために“アクティブ 80 ヘルスプラン”とい う計画を立てている。この “80”とはいうまでもなく 80 歳の意味であり, 80 歳になっても健やかにしかも active に過ごそうという願いが込めら机ている。しかるにわが 国の平成若年者層の間ではアメリカ人の子供よりも血中 総コレステロール量が多い人の数が著しく増えており, わが国が長寿世界一の座を追われることも一世代を待た ずしてくるようにもみうけられる。このことに加えてこ のところ乳幼児を中心にアトピー性皮䖉炎が非常な勢い で増えているが, この理由の一つに $n-6$ 系脂肪酸 $/ n-3$ 系脂肪酸比のインバランスが挙げら机ている。すなわち 皮膚にロイコトリエン $\mathrm{B}_{4}$ が増えると種々の皮膚疾患が 起こることが知られているが，アトピー性皮膚炎の病因 にもロイコトリエン $B_{4}$ が重要な役割を果たしていると いうのである。いうまでもなくロイコトリエン $\mathrm{B}_{4}$ はア ラキドン酸から産生されるので, EPA を摄机皮䖉疾 患の原因とはならないロイコトリエン $\mathrm{B}_{5}$ を産生させて 体内でのロイコトリエン $\mathrm{B}_{4}$ の産生をきっ(拮)抗的に抑 制することになる ${ }^{129) .130)}$ 。したがってこういった方面 からもEPAが注目されるところとなっており,これか らの日本人が EPA やDHA を日常的に摂取していくこ とはますます重要になっていくであろう。

一方, 最近 $\mathrm{EPA} や \mathrm{DHA}$ を中心した HUFA を 積極的に摂取することに対して異論をとなえる論文が奥 山帛) によって出され (本号 “植物性不飽和油脂の利用” 参照) 話題になっている。欧米ではまず油脂の摄取総量 を減らすことが第一目的とされ, 油脂の質(脂肪酸の質) の問題はどちらかといえば次ぎの問題であるとされてい る ${ }^{131)}$ 。しかし現実には従来までの脂肪摂取過多の食生 活様式を大きく変えることは難しく, “量”之“質”の 問題のうち取り組みやすいものから始め上うといった状 況にある。そのあらわ机冒頭でも述べた植物油代替(未 水添魚油混合）マーガリンやスプレッドの製造の試みの 例であろう。わが国においても食生活が急速に欧米化し ている今日, 油脂摂取の総量を減らすということは脂質 とは全く化学構造の異なった油脂代替品（一部には例あ り ${ }^{131)}$ ) でも開発されない限りほとんど不可能である。 こうしたことを考え合わせると, 現実的な対応策として はいかに現在の油脂摂取総量を超えないように維持し, いかにリノール酸を $n-3$ 系脂肪酸に置き換えることがで きるかという問題に帰属されてくるように思われる。3・1 でも述べたように精製直後の魚油は無臭である。した がってこの状態を維持できれば理屈の上ではリノール酸 の代替がきくことになる。問題はこれを可能とするため にいかに酸素を遮断したり，いかにHUFA を安定化さ せるかである。酸素を遮断する方法としてはデキストリ ン.132), 卵白ペプチド (Fig.ー1 1) ${ }^{133)}$, シクロデキストリ ン等で包埋するマイクロカプセル化の技術が開発されて

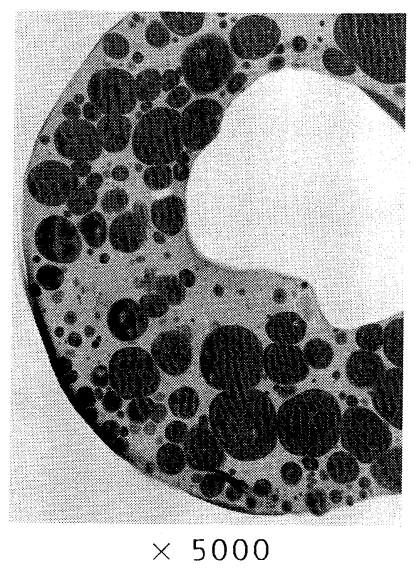

Fig.-1 A cross-sectional view of albumen glair peptide micro capsule of EPA rich oil ${ }^{133}$.

いる。シクロデキストリンによる HUFA のマイクロカ プセル化には前向きになれないとする向きもあるが, 食 品工業上扱いやすくするためには粉末化することが極め て効果的であることは疑う余地がない。しかし反面, 食 品素材の一部としての油脂そのもののもつ良さを活かそ うとすればそのままの形で利用する形態を重視する見方 も当然出てくる。この際には抗酸化剂の併用や油脂の安 定性を賦与する天然物質の添加が必然となろう ${ }^{134)}$ 。天 然酸化防止性物質に関する研究は昔から広く行われてお り, 各種の香辛料, 茶, 生薬に関する研究は枚挙にいと まがない ${ }^{135)}$ 。このところセサモールやその誘導体の酸 化防止性 ${ }^{136)}$ ．137) も注目されてはいるがいずれも価格や 供給量の点で $\alpha$-トコフェロールよりも不利よなってい る。しかし今後は積極的にこれらの酸化防止性物質を組 み合わせることによって HUFA 含有油の特性を活かし た食品を開発できる可能性は充分にある。また先に述べ たように水産物は多くの場合それ自身は天然酸化防止性 物質の含量が非常に低いが，その中に含まれているリン 脂質がトコフェロールと相乗的に酸化防止性を発揮する

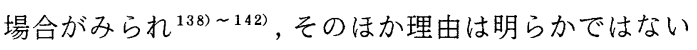
がハ夕ハ夕の脂質やイカのリン脂質 ${ }^{143}$ が酸化防止性を 示すという報告もある。したがって場合によってはこれ らの脂質を混合することによっても HUFA 含有油の安 定性を賦与することができるとも考えられ, 魚油の利用 方途拡大にむすびつく可能性もある。さらに付け加える ならば HUFA 含有油の食品への添加形態の工夫によっ ても, 新たな魚油の利用拡大が見込めよう。すなわち HUFA を水中分散させた場合は著しく酸化速度が遅い とする報告が出されており $(\text { Fig-2 })^{144)}$, 145), 食品への 添加形態の工夫によって抗酸化剂にそれほよ゙頼らずに消 費拡大を図れる可能性もある。事実, 野中らによって魚 肉の水中粉砕の技術が確立されており ${ }^{146)}$, これによっ 


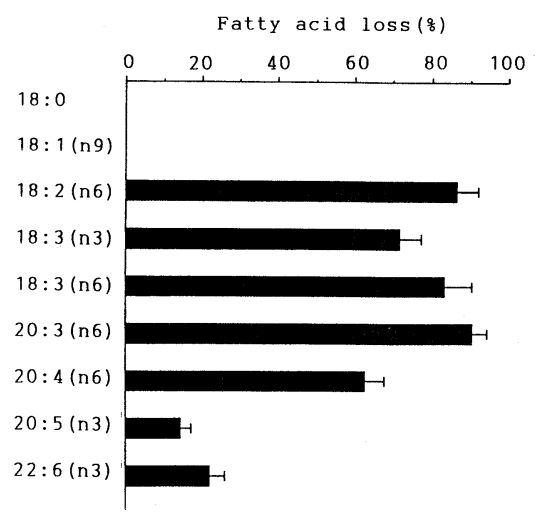

Fatty acid oxidation, expressed by the fatty acid loss in percent, was estimated by calculating the difference between the initial concentration of fatty acid and the concentration after $24 \mathrm{~h}$ of UV irradiation. Peroxidation conditions : Five $\mathrm{mL}$ each of different fatty acid aqueous solution $(2 \mathrm{mM})$ was exposed to UV light $(254 \mathrm{~nm})$ at $23^{\circ} \mathrm{C}$ for $24 \mathrm{~h}$. Each sample was assayed in duplicate. Evaporation of solvent during the exposition was negligible. Results are the mean values of six determinations.

Fig. -2 Fatty acid oxidation as a function of degree of unsaturation ${ }^{144)} \cdot 145$ ).

て得られる魚油は傷みがほとんどないといわれる。この 理由については定かではないが, ビタミン E の濃縮効 果 ${ }^{147)}$ のほか空気の遮断や水のラジカル水和作用 ${ }^{148)}$ が 一因とも考えられる。HUFA の水中分散はまた生体吸 収利用率も大幅に向上させるという報告 ${ }^{149)}$ があり, 今 後大いに検討すべき点である。

\section{7 おりに}

厚生省機能性食品検討委員会報告書 (1990 年) によれ ば,機能性食品は“日常的”なものでなければならない。 現在われわれはいろいろな形で毎日油脂類を相当量摂取 している。したがってこの極めて日常的な食用油脂類の 摂取総量を現在の水準に抑え，質的に少しでも改善でき ればその恩恵ははかりしれない。

昨年, 日常的な食品の代表格である豆腐に HUFA を 添加したものが出願され ${ }^{150)}$ ，これと前後して各方面で $\mathrm{EPA}$ や DHA を各種食品に添加した場合の影響を検討 することが盛んに行われるようになった。しかし筆者個 人の見解としては HUFA の食品への “添加”よりは食 品中の油脂の “置き換え”に関する技術を推進すべきと 考えている。そのためには対象とする食品に合った脂質 を調製することが必要であり，筆者が “組み立て脂質” なるこよばを提唱するゆえんでもある。
[平成 3 年 (1991 年) 4 月 30 日受理]

\section{文献}

1) Anon., Inform, 1, 114 (1990)

2) Anon., J. Am. Oil Chem. Soc., 66, 1717 (1989)

3) Anon., Inform, 1, 952 (1990)

4) Anon., Inform, 1, 731 (1990)

5）矢澤一良, “マリンバイオ”, 株式会社シーエムシー, (1989), p. 99

6）矢澤一良, 荒木恵子, 渡部和郎, 石川千夏子, 井上 玲, 近藤 聖, 渡部終五, 橋本培久, 日水誌, 54, 1835 (1988)

7）新免芳史, 月刊フードケミカル, 1990 (12), 53

8）清水 昌,山田秀明, 月刊フードケミカル, 1991 (1), 71

9) Anon., J. Am. Oil Chem. Soc., 66, 1531 (1989)

10）木村省二, 藤本健四郎, 西川正純, 公開特許, 平 249723

11）島村馬次郎, “水産油糧学”（外山健三, 高木 徹, 渡辺 武 編), 恒星社厚生閣, (1988), p. 133

12）渡辺 武, “養魚と飼料脂質” (日本水産学会編), 恒星 社厚生閣, (1978), p. 93

13）手島新一, “養魚之飼料脂質” (日本水産学会編), 恒星 社厚生閣, (1978), p. 60

14）竹田正彦, “養魚と飼料脂質” (日本水産学会編), 恒星 社厚生閣, (1978) p. 78

15) 渡辺 武, “水産油糧学” (外山健三, 高木 徹, 渡辺 武 編), 恒星社厚生閣, (1988), p. 171

16) Anon., Inform, 1, 638 (1990)

17）小泉千秋, “水産食品学” (須山三千三, 鴻单章二編), 恒星社厚生閣, (1987), p. 184

18) M. E. Stansby, Food Tech., 16, 28 (1962)

19）中村弘二, 岡崎恵美子, 小堺由美子, 平成 3 年度日本 水産学会春季大会, 講演要旨集 (1991), p. 857

20) T. Miyazawa, M. Yamaguchi, J. Lee, K. Fujimoto, T. Kaneda, Agric. Biol. Chem., 48, 1375 (1984)

21) K. Fujimoto, "Flavor Chemistry of Lipid Foods" (D.B. Min, T.H. Smouse 編), Am. Oil Chem. Soc., (1989), p. 190

22) G. R. Mizuno, E. McMeans, J. R. Chipault, J. Agric. Food Chem., 14, 229 (1966)

23) G. Jellinek, M. E. Stansby, Fish. Bull., 69, 215 (1971)

24) P. W. Meijboon, J. B. A. Stroink, J. Am. Oil Chem. Soc., 49, 555 (1972)

25) A.C. Noble, W.W. Nawar, J. Am. Oil Chem. Soc., 48, 800 (1971)

26) P. J. Ke, R. G. Ackman, B. A. Linke, J. Am. Oil Chem. Soc., 52, 349 (1975)

27) C. Karahadian, R.C. Lindsay, J. Am. Oil Chem., Soc., 66, 953 (1989)

28) H. T. Badings, J. Am. Oil Chem. Soc., 50, 334, (1973)

29) E. N. Frankel, "Flavor Chemistry of Fats and Oils” (D.B. Min, T.H. Smouse 編), Am. Oil Chem. Soc., (1985) 
30) L. Crawford, M.J. Kretsch, D. Guadagni, J. Sci. Food Agric., 27, 531 (1976)

31) J.G. Kepper, J.A. Schols, W.H. Feensta, P. W. Meijboom, J. Am. Oil Chem. Soc., 42, 246(1965)

32) C. Karahadian, R.C. Lindsay, J. Am. Oil Chem., Soc., 67, 85 (1990)

33) M. Takao, US Pat. 4,554,107 (1985)

34) M. Takao, US Pat. 4,623,488 (1986)

35）太田静行, “魚臭・畜肉臭” (太田静行編), 恒星社厚生 閣, (1981), p. 89

36) N. Ikeda, K. Fukuzumi, J. Jpn. Oil Chem. Soc. (Yukagaku), 27, 26 (1978)

37) S. Cho, K. Miyashita, T. Miyazawa, K. Fujimoto, T. Kaneda, J. Am. Oil Chem. Soc., 64, 876 (1987)

38) S. Cho, Y. Endo, K. Fujimoto, T. Kaneda, Nippon Suisan Gakkaishi, 55, 545 (1989)

39）藤本健四郎，水産の研究， 8, 56 (1989)

40）羽田野六男, 高橋是太郎, 平成元年度水産物健康性機 能有効利用開発研究の成果の概要 (水産庁研究部研究 課) (1989), p. 260

41) Anon., Inform., 1, 987 (1990)

42) R.G. Ackman, Acta Medica Scandinavica, 222, 99 (1987)

43) X. Yan, P.J. Barlow, C. Craven, Food Chem., 40, 93 (1991)

44) R.G. Ackman, N.C. Shantha, A. M. Timmins, Inform, 4, 296 (1990)

45) A.F. Prevot, F.X. Mordret, Rev. Fse. Corps Gras. , 23, 409 (1976)

46) T. Tande, T. Granvik, Inform, 1, 302 (1990)

47) L. D. Metcalfe, C.N. Wang, J. Chromatogr. Sci., 19, 530 (1981)

48) Anon., スペルコリポー夕ー, 9, 4 (1989)

49）和田 俊, “水産動物の筋肉脂質” (鹿山 光 編), 恒星 社厚生閣, (1985), p. 9

50) K. Takahashi, T. Hirano, K. Takama, K. Zama, Nippon Suisan Gakkaishi, 48, 1803 (1982)

51) T. Ohshima, S. Wada, C. Koizumi, Nippon Suisan Gakkaishi, 49, 123 (1983)

52）大島敏明, 小泉千秋, 日水誌, 49, 1205 (1983)

53）大島敏明,和田 俊, 小泉千秋, 日水誌, 49, 1213(1983)

54）大島敏明,和田 俊.小泉千秋, 日水誌. 49, 1397(1983)

55）大島敏明,和田 俊, 小泉千秋, 日水誌, 50, 107(1984)

56) T. Ohshima, S. Wada, C. Koizumi, Nippon Suisan Gakkaishi, 50, 2091 (1984)

57) K. Takahashi, H. Ebina, M. Egi, K. Matsumoto, K. Zama, Nippon Suisan Gakkaishi, 51, 1475 (1985)

58) K. Takahashi, M. Egi, K. Zama, Nippon Suisan Gakkaishi, 51, 1487 (1985)

59) K. Takahashi, Mem. Fac. Fish. Hokkaido Univ. 32, 245 (1985)

60）高橋是太郎, “水産動物の笳肉脂質” (鹿山 光 編), 恒 星社厚生閣, (1985), p. 24

61 ) 和田 俊, “総合脂質科学” (鹿山 光 編), 恒星社厚生 閣, (1989), p. 110
62) K. Takahashi, T. Hirano, J. Jpn. Oil Chem. Soc. (Yukagaku), 40, 277 (1991)

63) Anon., Inform, 1, 638 (1990)

64) M.M. Mahfouz, S. Johnson, R.T. Holman, Lipids, 15, 100 (1980)

65) Biochim. Biophys. Acta, 663, 58 (1981)

66) E. A. Emken, J. Am. Oil Chem. Soc., 66, 439 (1989)

67) 奥山治美, 化学々生物, 28, 175 (1990)

68) K.M. Chee, J.X. Gong, D.M. G. Ree, M. Meydani, L. Ausman, J. Johnson, E. N. Siguel, E. J. Schaefer, Lipids, 25, 523 (1990)

69）片平亮太, .“健康食品の精製・加工技術, 健康食品開発 マニュアル” (岩尾裕之他共著), 株式会社シーエム シー, (1983)

70）高橋是太郎, 澤田哲志, 羽田野六男, 平成 3 年度日本 水産学会春期大会講演要旨集, (1991), p. 272

71) F.D. Gunstone, J.L. Harwood, "The Lipid Handbook" (F.D Gunstone, J.L. Harwood, F.B. Padley 編), Chapman and Hall, (1986), p. 171

72) V.F. Stout, J. Am. Oil Chem. Soc., 40, 40(1963), and its references.

73) 佃 伸夫, 食品工業, 28 (9下), 30 (1985)

74) W. Eisenbach, Ber. Bunsenges. Phy. Chem., 88, $882(1984)$

75）斉藤功夫, 食品工業, 28 (9下), 37 (1985)

76) W.B. Nilsson, V.F. Stout, J.K. Hudson, J. Am. Oil Chem. Soc., 63, 470 (1986)

77) W.B. Nilsson, E.J. Gauglitz, J.K. Hudson, V. F. Stout, J. Spinelli, J. Am. Oil Chem. Soc., 65, 109 (1988)

78) W.B. Nilsson, E.J. Gauglitz, J.K. Hudson, F. M. Teeny, Am. Oil Chem. Soc. Anual meeting, (1988)

79) W.B. Nilsson, E.J. Gauglitz, J.K. Hudson, J. Am. Oil Chem. Soc., 66, 1596 (1989)

80) R. G. Ackman, Chem. Ind. London, 1988, 139

81) Anon., Inform, 1, 814 (1990)

82) N. Haagsma, J. Am. Oil Chem. Soc., 59, 117 (1982)

83) S.W. Wright, E.Y. Kuo, E.J. Corey, J. Org. Chem., 52, 4399 (1987)

84) E.J. Corey, S.W. Wright, J. Org. Chem., 53, 5980 (1988)

85) D.R. Tocher, A. Webster, J.R. Sargent, Biotechnol. Appl. Biochem., 8, 83 (1986)

86) S. Tokiwa, A. Kanazawa, S. Teshima, Nippon Suisan Gakkaishi, 47, 675 (1981)

87）日経産業新聞, 平成 3 年 4 月 4 日号

88）日刊工業新聞, 平成 2 年 11 月 24 日号

89）尔澤一良, 渡部和郎, 石川千夏子, 斉藤政則, 近藤 聖, 平成 3 年度日本水産学会春期大会講演 要 旨 集, (1991), p. 269

90）村瀬行信，鈴木一昭，斉藤房幸，公開特許，昭 58165796

91）安田 聖, 松本 渉, 中井英二, 公開特許, 昭 60234589 
92) T. Hoshino, T. Yamane, S. Shimizu, Agric. Biol. Chem., 54, 1459 (1990)

93）星野 保, 山根恒夫, 清水祥一, 農化誌, 64, 241(1990)

94）山根恒夫. 星野 保, Bio Industry, 7, 47 (1990)

95) H. Brockerhoff, J. Lipid Res., 6, 10 (1967)

96) N.R. Bottino, G.A. Vandenberg, R. Reiser, Lipids, 2, 489 (1967)

97) H. Brockerhoff, Biochim. Biophys. Acta., 212, 92 (1970)

98）中野 章, 木村義晴, 公開特許, 昭 61-15692

99）中野 章, 木村義晴, 公開特許, 昭 61-15693

100）村瀬行信, 鈴木一昭, 中井英二, 公開特許, 昭 60130396

101）村瀬行信, 鈴木一昭, 松本 渉, 中井英二, 公開特許, 昭 60-234590

102）藤吉隆司，横江正明，間瀬民生，公開特許，昭 62171691

103) P. Langholz, P. Andersen, T. Forskov, W. Schmidtsdorff, J. Am. Oil Chem. Soc., 66, 1120 (1989)

104) M.J. Hills, I. Kiewitt, K.D. Mukherjee, J. Am. Oil Chem. Soc., 67, 561 (1990)

105) M.J. Hills, I. Kiewitt, K.D. Mukherjee, Biochim. Biophys. Acta., 1042, 237 (1990)

106) M. Iwai, Y. Tsujisaka, J. Fukumoto, J. Gen. Appl. Microbiol., 10, 13 (1964)

107）山田 理, 藤田 匡, 公開特許, 昭 62-91188

108) Y. Tanaka, J. Hirano, R. Hashizume, T. Okuchi, T. Funada, ISF-JOCS World Congress 1988, Abstracts, (1988), p. 291

109) Y. Tanaka, J. Hirano, R. Hashizume, T. Okuchi, T. Funada, Proceedings of Session Lectures and Scientific Presentations on ISF-JOCS World Congress 1988, (1988), p. 1083

110）船田 正, 田中幸久, 食品工業, 20 (1989)

111）田中幸久, 油脂, 42, 234 (1989)

112）高橋弘憲, 蔵重 淳, 公開特許, 平1-120295

113）国生純孝，大島章夫，角田 昭，岩崎慎二郎，公開特 許, 平 $1-137988$

114）岡畑惠雄, 公開特許, 昭 64-80297

115）長田恭一, 高橋是太郎, 羽田野六男, 平成 2 年度日本 水産学会春期大会講演要旨集, (1990), p. 230

116）長田恭一, 高橋是太郎, 羽田野六男, 細川雅史, 日水 誌, 57, 119 (1991)

117） 戸谷洋一郎, 渡部 健, 原 節子, 第 44 回日本栄養 · 食糧総会講演要旨集, $(1990)$, p. 77

118）原 節子, 渡部 健, 戸谷洋一郎, 第 29 回油化学討論 会・油化学研究発表会講演要旨集, (1990), p. 189

119）稲田裕二, 公開特許, 昭 63-105686

120) T. Yoshimoto, T. Nakata, S. Yamaguchi, T. Funada, Y. Saito, Y. Inada, Biotechnol. lett., 8 , 771 (1986)

121) T. Yagi, T. Nakanishi, Y. Yoshizawa, F. Fukui,
J. Ferment. Bioeng., 69, 23 (1990)

122）手島新一, 金沢昭夫, 堀之内浩司, 昭和 61 年度日本水 産学会春期大会講演要旨集, (1986), p. 41

123）松本啓次郎, 森田育夫, 日比野英彦, 平野次郎, 室田 誠逸, 生化学, 61, 1078 (1989)

124) A. Na, C. Eriksson, S.G. Eriksson, E. Osterberg, K. Holmberg, J. Am. Oil Chem. Soc., 67, 766 (1990)

125) P. Pernas, J.L. Olivier, M.D. Legoy, G. Bereziat, Biochem. Biophysi. Res. Commun., 168, 644 (1990)

126）細川雅史, 高橋是太郎, 羽田野六男, 赤澤治夫, 平成 3 年度日本水産学会春期大会講演要旨集, (1991),p. 274

127）細川雅史, 高橋是太郎, 羽田野六男, 江木 衷, 食工 誌, 38, 695 (1991)

128）伊東裕匹，月刊フードケミカル, 1990 (12), 29

129) C.C. Miller, R.Y. Yamaguchi, V.A. Zibou, Lipids, 24, 998 (1989)

130）鳥居新平, “アレルギーの衣食住チェック”, 農産漁村文 化協会, (1990), p. 155

131) 長光正明, 高橋禮治, New food Industry, 33 (2), 53 (1991)

132）化工日報, 平成 2 年 12 月 4 日号

133）濱千代善規, 長谷川莑夫. New Food Industry, 31 (9), 12 (1989)

134）齊藤洋昭, 食品工業, 33 (6), 35 (1990)

135) 山口直彦, New Food Industry, 32 (1), 68, (1990)

136) T. Osawa, M. Nagata, M. Namiki, Y. Fukuda, Agric. Biol. Chem., 49, 3351 (1985)

137）大澤俊彦, 油化学, 38, 839 (1989)

138) J. Lee, K. Fujimoto, T. Kaneda, Nippon Suisan Gakkaishi, 47, 881 (1981)

139) J. Lee, K. Fujimoto, T. Kaneda, Agric. Biol. Chem., 47, 2001 (1983)

140) J. Lee, K. Fujimoto, T. Kaneda, Nippon Suisan Gakkaishi, 50, 1863 (1984)

141）豊水正道, 日水誌, 50, 1245 (1984)

142）豊水正道, 日水誌, 50, 1897 (1984)

143) I. Komatsu, T. Yasuda, T. Suzuki, K. Fukunaga, S. Suzuki, K. Takama, Bull. Fac. Fish. Hokkaido Univ. , 41, 232 (1990)

144) E. Bruna, E. Petit, M. Beljian-Leymarie, S. Huynh, A. Nouvelot, Lipids, 24, 970 (1989)

145）影山治夫, 月刊フードケミカル, 1990 (11), 106

146）野中道夫, “魚肉の栄養成分とその利用”(竹内昌昭編), 恒星社厚生閣, (1990), p. 88

147）川崎賢一, 大泉 徹, 本江 薫, 野中道夫, 平田史生, 佐伯宏樹, 平成元年度日本水産学会春期大会講演要旨 集, (1989), p. 264

148）豊水正道, “食品の水”（日本水産学会編）, 恒星社厚生 閣, (1973), p. 124

149) W. S. Harris, J. Lipid Res., 30, 769 (1989)

150）日本油脂株式会社, 公開特許, 平 2-18824 